\title{
35. PHYSICAL PROPERTIES OF BASALT SAMPLES FROM DEEP SEA DRILLING PROJECT SITE $597^{1}$
}

\author{
Robin L. Newmark, Lamont-Doherty Geological Observatory and Department of Geological Sciences, \\ Columbia University \\ and \\ Daniel Moos, Lamont-Doherty Geological Observatory, Columbia University²
}

\begin{abstract}
The bulk and grain densities, porosity, water content, and ultrasonic compressional- and shear-wave velocities of 25 basalt samples from DSDP Holes 597B and 597C were measured. The velocities were measured at in situ pore and confining pressures. The bulk densities of the samples vary between 2.690 and $3.050 \mathrm{~g} / \mathrm{cm}^{3}$. Porosities of selected samples vary between 2.4 and $9.3 \%$. The grain densities vary between 2.993 and $3.117 \mathrm{~g} / \mathrm{cm}^{3}$, a range that suggests that bulk density differences are due primarily to variations in porosity. Compressional-wave velocities range from 5.70 to $6.81 \mathrm{~km} / \mathrm{s}$, and shear-wave velocities range from 1.66 to $3.84 \mathrm{~km} / \mathrm{s}$. The variation in compressional velocity appears to be due primarily to variations in grain size and the associated greater density of grain-boundary cracks for samples with a smaller average grain size. On the basis of these results we would expect compressional and shear velocities to increase with increasing depth in the shallow crust, primarily as the result of the effects of confining pressure on crack density.
\end{abstract}

\section{INTRODUCTION}

Laboratory measurements of compressional-wave and shear-wave velocities in core recovered by ocean drilling are essential to the interpretation of marine geophysical data (particularly seismic refraction data) and contribute to our understanding of the composition of the crust through comparison with petrological models. Moreover, laboratory physical property measurements of samples under in situ conditions provide information essential for the calibration of borehole logging tools and the interpretation of geophysical logs obtained in deep ocean holes. This paper describes laboratory measurements of the compressional and shear velocity, porosity, and density of representative samples obtained from cores recovered at DSDP Site 597.

During Leg 92, Hole 597C was drilled to a depth of $91 \mathrm{~m}$ into 28.6-Ma basement, which was generated at the now-extinct but fast-spreading Mendoza Rise. It represents the deepest re-entry hole yet drilled in oceanic crust generated at a fast-spreading ridge. The basalts are described in detail in the Site 597 chapter, Pearce et al., and Goldfarb (all this volume). They are olivine-poor to olivine-free ferrobasalts characteristic of fast-spreading ridges, containing plagioclase, clinopyroxene, magnetite, glass, and olivine. They are medium- to fine-grained, moderately vesicular (in the upper $40 \mathrm{~m}$ or so), and fractured. Massive flows appear to make up the entire sequence. Only one small fragment with a glassy rim, possibly a pillow margin, was recovered (Site 597 chapter, this volume). The basement section was divided into three units on the basis of its general geochemical and pet-

\footnotetext{
${ }^{1}$ Leinen, M., Rea, D. K., et al., Init. Repts. DSDP, 92: Washington (U.S. Govt. Printing Office). Lamont-Doherty Geological Observatory Contribution No. 3955.

2 Addresses: (Newmark, present address) Lawrence Livermore National Laboratory, Livermore, CA 94550; (Moos) Borehole Research Group, Lamont-Doherty Geological Observatory, Columbia University, Palisades, NY 10964.
}

rographic characteristics. Unit I ( 0 to $48 \mathrm{~m}$ into basement) contains olivine and both plagioclase glomerocrysts and phenocrysts. These phases are absent in Unit II (48 to $66 \mathrm{~m}$ into basement). In Unit III (from $66 \mathrm{~m}$ to total depth), olivine is present (Pearce et al., this volume).

\section{RESULTS}

\section{Velocity Measurements}

We measured the compressional- and shear-wave velocities of 2 samples from Hole 597B and 23 samples from Hole 597C. The samples represent the complete range of textures and compositions present in the recovered core. The samples are right cylinders about $25 \mathrm{~mm}$ in diameter and $19 \mathrm{~mm}$ in height. The ends of the cylinders were surface ground to $\pm 0.0003 \mathrm{~cm}$ to ensure good transducer coupling and to maintain surface parallelism. The samples were kept saturated with seawater from the time of their recovery and throughout the measurements. Distilled water was used in the experimental apparatus for elevating pore pressure.

The compressional and shear velocities were measured at in situ pore and confining pressures. These conditions contrast with those of many previous experiments (e.g., Hyndman, 1977; Wilkens et al., 1983), in which velocities were measured at elevated confining pressures under conditions that kept pore pressure to a minimum. In this study, confining pressures were determined by calculating the weight of the water, sediment, and rock overlying the depth from which the sample was obtained; the calculations were made by using shipboard density measurements (Site 597 chapter, this volume). Pore pressures (Table 1) were determined by calculating the weight of the seawater overlying the depth from which the sample was obtained; the calculations were made by using a value of water density of $1.025 \mathrm{~g} / \mathrm{cm}^{3}$ for the water column above the seafloor and $1.046 \mathrm{~g} / \mathrm{cm}^{3}$ for water at sub- 
Table 1. Physical properties of basalt samples from Holes 597B and 597C.

\begin{tabular}{|c|c|c|c|c|c|c|c|c|}
\hline $\begin{array}{l}\text { Sample } \\
\text { number }\end{array}$ & $\begin{array}{l}\text { DSDP sample } \\
\text { number } \\
\text { (interval in } \mathrm{cm} \text { ) }\end{array}$ & $\begin{array}{c}\text { Bulk } \\
\text { density } \\
\left(\mathrm{g} / \mathrm{cm}^{3}\right)\end{array}$ & $\begin{array}{l}\text { Grain } \\
\text { density } \\
\left(\mathrm{g} / \mathrm{cm}^{3}\right)\end{array}$ & $\begin{array}{c}\text { Porosity } \\
(\%)\end{array}$ & $\begin{array}{l}\text { Confining } \\
\text { pressure } \\
\text { (bars) }\end{array}$ & $\begin{array}{l}\text { Pore } \\
\text { pressure } \\
\text { (bars) }\end{array}$ & $\begin{array}{l}\text { Compressional } \\
\text { velocity } \\
(\mathrm{km} / \mathrm{s})\end{array}$ & $\begin{array}{l}\text { Shear } \\
\text { velocity } \\
(\mathrm{km} / \mathrm{s})\end{array}$ \\
\hline 1 & $597 \mathrm{~B}-2-1,12-14$ & 2.809 & 2.994 & 9.3 & 436 & 428 & 5.72 & 1.66 \\
\hline 2 & $597 \mathrm{~B}-2-2,11-13$ & 2.714 & & & 437 & 428 & 5.73 & \\
\hline 3 & $597 C-3-1,119-121$ & 2.690 & & & 436 & 428 & 5.70 & \\
\hline 4 & $597 C-3-3,29-31$ & 2.867 & 3.046 & 8.7 & 437 & 428 & 5.74 & 2.79 \\
\hline 5 & $597 C-4-2,136-138$ & 2.964 & & & 439 & 429 & 6.25 & \\
\hline 6 & $597 C-4-4,91-93$ & 2.995 & 3.071 & 3.6 & 440 & 429 & 6.23 & 2.92 \\
\hline 7 & $597 C-4-6,45-47$ & 2.971 & & & 441 & 430 & 6.10 & \\
\hline 8 & $597 C-5-2,57-59$ & 2.994 & 3.102 & 5.1 & 441 & 430 & 6.40 & \\
\hline 9 & $597 C-6-1,114-116$ & 2.896 & 2.993 & 4.8 & 444 & 432 & 6.20 & \\
\hline 10 & $597 C-6-3,122-124$ & 3.016 & 3.066 & 2.4 & 445 & 431 & 6.58 & \\
\hline 11 & $597 C-6-4,122-124$ & 2.827 & & & 446 & 432 & 5.74 & \\
\hline 12 & $597 C-7-1,50-52$ & 3.010 & & & 446 & 432 & 6.79 & \\
\hline 13 & $597 C-7-2,22-24$ & 3.020 & 3.117 & 4.6 & 448 & 432 & 6.30 & 3.32 \\
\hline 14 & $597 C-8-1,134-136$ & 2.902 & & & 449 & 433 & 5.87 & \\
\hline 15 & $597 C-8-2,68-70$ & 2.982 & 3.114 & 6.2 & 450 & 433 & 5.81 & \\
\hline 16 & $597 C-8-5,35-37$ & 2.897 & 3.032 & 6.7 & 451 & 433 & 6.17 & 3.48 \\
\hline 17 & $597 C-9-1,99-101$ & 2.835 & & & 452 & 434 & 5.72 & 2.78 \\
\hline 18 & $597 C-9-3,49-51$ & 2.879 & 3.021 & 7.0 & 456 & 435 & 5.81 & \\
\hline 19 & $597 \mathrm{C}-9-4,113-115$ & 2.864 & & & 453 & 434 & 5.77 & \\
\hline 20 & $597 C-10-2,135-137$ & 3.050 & 3.116 & 2.7 & 456 & 436 & 6.74 & 3.09 \\
\hline 21 & $597 C-10-4,108-110$ & 2.924 & & & 456 & 435 & 6.72 & 3.84 \\
\hline 22 & $597 \mathrm{C}-10-7,71-73$ & 2.953 & 3.027 & 3.6 & 458 & 436 & 6.34 & \\
\hline 23 & $597 \mathrm{C}-11-1,104-106$ & 2.880 & & & 458 & 436 & 6.53 & 2.75 \\
\hline 24 & $597 \mathrm{C}-11-2,48-50$ & 2.933 & 3.025 & 2.8 & 457 & 436 & 6.58 & \\
\hline 25 & $597 \mathrm{C}-11-3,35-37$ & 2.930 & & & 458 & 436 & 6.81 & \\
\hline
\end{tabular}

bottom depths (Craig et al., 1981). It was assumed in making these calculations that the upper oceanic crust is sufficiently permeable so that the rock at depth is subjected to hydrostatic pore pressure. Packer tests performed in Hole 597C support this assumption inasmuch as the preliminary results indicate a permeability of over 100 millidarcies (Site 597 chapter, this volume). The Kuster records, however, showed that the formation was underpressured by about 5 bars, which suggests that our pore pressure estimates may be slightly high. A change of 5 bars will not affect the results significantly, however.

Traveltimes through the minicores were measured by using a pulse-transmission technique (e.g., Birch, 1960, 1961). The experimental design is described by Tosaya (1982). In the experimental apparatus used, the source and receiver transducers are not bound directly to the sample but reside in aluminum end caps, which are pressed against the sample. Increasing the pore pressure injects fluid between the end caps and the sample, disrupting the surface coupling between the sample and end caps. After a period of time, the fluid diffuses into the sample and proper surface coupling is re-established. All velocity measurements were made at least $12 \mathrm{hr}$. after the pore pressure was elevated, which was considered sufficient time for the diffusion of fluid to be completed. Accurate measurements of shear velocity were obtained in only 9 of the 25 samples because of the inherent difficulty of determining shear-wave arrival times at low effective pressures. The timing of arrivals is accurate to $\pm 0.1 \mu \mathrm{s}$, with the result that the accuracy of the velocity measurements is about $3.5 \%$ for compressional and $1.3 \%$ for shear waves.

As shown in Table 1, compressional velocities range from $5.70 \mathrm{~km} / \mathrm{s}$ in Sample 1 (597C-3-1, 119-121 cm; highly vesicular) to $6.81 \mathrm{~km} / \mathrm{s}$ in Sample 25 (597C-11-3, $35-37 \mathrm{~cm}$; medium grained, nearly fresh). The mean (and standard deviation) of compressional velocity for the 25 samples is $6.17 \pm 0.38 \mathrm{~km} / \mathrm{s}$. Shear velocities range from $1.66 \mathrm{~km} / \mathrm{s}$ in Sample 1 (597-2-1, 12-14 cm; highly vesicular) to $3.84 \mathrm{~km} / \mathrm{s}$ in Sample 21 (597C-10-4, 108-110 $\mathrm{cm}$; medium grained). The mean shear velocity is 2.96 $\pm 0.57 \mathrm{~km} / \mathrm{s}$.

The compressional velocities of 16 of these samples were measured on board ship as well (Site 597 chapter, this volume). These measurements are compared with our results in Table 2 . The shipboard measurements were made at atmospheric temperature and pressure using a Hamilton frame velocimeter. Since the shipboard samples were not surface ground, significant errors may occur in the estimation of the path length, which will in

Table 2. Comparison between laboratory and shipboard-measured values of compressional and shear velocity and bulk density.

\begin{tabular}{|c|c|c|c|c|c|}
\hline $\begin{array}{l}\text { Sample } \\
\text { number }\end{array}$ & $\begin{array}{l}\text { DSDP sample } \\
\text { number } \\
\text { (interval in } \mathrm{cm} \text { ) }\end{array}$ & $\begin{array}{l}\text { Shipboard } \\
\text { compressional } \\
\text { velocity } \\
(\mathrm{km} / \mathrm{s})\end{array}$ & $\begin{array}{c}\text { Difference in } \\
\text { compressional } \\
\text { velocity } \\
(\%)\end{array}$ & $\begin{array}{c}\text { Shipboard } \\
\text { bulk } \\
\text { density } \\
\left(\mathrm{g} / \mathrm{cm}^{3}\right)\end{array}$ & $\begin{array}{c}\text { Difference } \\
\text { in bulk } \\
\text { density }{ }^{\mathrm{a}} \\
(\%)\end{array}$ \\
\hline 1 & $597 \mathrm{~B}-2-1,12-14$ & & & 2.83 & 0.7 \\
\hline 3 & $597 \mathrm{C}-3-1,119-121$ & 5.15 & -9.6 & 2.71 & 0.7 \\
\hline 4 & $597 C-3-3,29-31$ & 5.49 & -4.3 & 2.84 & -0.9 \\
\hline 5 & $597 \mathrm{C}-4-2,136-138$ & 5.75 & -8.0 & 2.97 & 0.2 \\
\hline 7 & $597 C-4-6,45-47$ & 5.77 & -5.4 & 2.91 & -2.0 \\
\hline 8 & $597 C-5-2,57-59$ & 5.81 & -9.2 & 2.91 & -2.8 \\
\hline 9 & $597 \mathrm{C}-6-1,114-116$ & 5.89 & -5.0 & 2.93 & 1.2 \\
\hline 11 & $597 \mathrm{C}-6-4,122-124$ & 5.32 & -7.3 & 2.86 & 1.1 \\
\hline 12 & $597 C-7-1,50-52$ & 6.13 & -9.7 & 2.97 & -1.3 \\
\hline 14 & $597 \mathrm{C}-8-1,134-136$ & 5.55 & -5.5 & 2.92 & 0.6 \\
\hline 16 & $597 C-8-5,35-37$ & 5.6 & -9.2 & 2.92 & 0.7 \\
\hline 17 & $597 C-9-1,99-101$ & 5.58 & -2.4 & 2.92 & 2.9 \\
\hline 18 & $597 C-9-3,49-51$ & 5.50 & -5.3 & 2.91 & 1.6 \\
\hline 20 & $597 \mathrm{C}-10-2,135-137$ & 6.48 & -3.9 & 2.97 & -2.6 \\
\hline 22 & $597 \mathrm{C}-10-7,71-73$ & 6.08 & -4.1 & 2.93 & -0.8 \\
\hline 23 & $597 \mathrm{C}-11-1,104-106$ & 6.11 & -6.4 & 2.93 & 1.7 \\
\hline 25 & $597 \mathrm{C}-11-3,35-37$ & 6.40 & -6.0 & 2.94 & 0.3 \\
\hline
\end{tabular}


turn affect the calculated velocities. Shipboard compressional velocities of these samples range from $5.15 \mathrm{~km} / \mathrm{s}$ in Sample $3(597 \mathrm{C}-3-1,119-121 \mathrm{~cm})$ to $6.48 \mathrm{~km} / \mathrm{s}$ in Sample 17 (597C-9-1, 99-101 cm). The shipboard velocity measurements are 2.4 to $9.7 \%$ lower than the velocities measured at in situ pressures in the laboratory (see Table 2). This difference is not unexpected, because compressional velocity should increase with increasing effective pressure. However, the measured velocities do not increase uniformly from sample to sample. This result emphasizes how important it is to make laboratory measurements at conditions that are as close to in situ as possible, especially if the results are intended for comparison with data from other sources, such as large-scale seismic experiments.

\section{Bulk and Grain Density}

Bulk density was determined by using the classical gravimetric method at atmospheric pressure and temperature. The samples were weighed on a Sartorius scale with an accuracy of $\pm 0.002 \mathrm{~g}$. They were all saturated with seawater, and their surfaces were wiped dry just before weighing, with the result that evaporative weight loss was negligible. The sample volumes were determined with an accuracy of $\pm 0.001 \mathrm{~cm}^{3}$ by weighing the samples again immersed in distilled water. The wet-bulk density can readily be determined within $\pm 0.001 \mathrm{~g} / \mathrm{cm}^{3}$, inasmuch as the samples are typically about $28 \mathrm{~g}$ in weight and about $9 \mathrm{~cm}^{3}$ in volume.

As shown in Table 1, the bulk densities range from $2.690 \mathrm{~g} / \mathrm{cm}^{3}$ for a vesicular sample (Sample 3; 597C-3-1, $119-121 \mathrm{~cm}$ ) to $3.050 \mathrm{~g} / \mathrm{cm}^{3}$ for a low-porosity sample (Sample 20; 597C-10-2, 135-137 cm). The mean bulk density of the 25 basalts is $2.912 \pm 0.088 \mathrm{~g} / \mathrm{cm}^{3}$, which is very close to the mean bulk density of the 29 samples measured on board ship $\left(2.92 \pm 0.056 \mathrm{~g} / \mathrm{cm}^{3}\right.$; Site 597 chapter, this volume).

Of the 29 samples measured for bulk density on board ship, we measured bulk densities on 17 in the laboratory. Bulk densities were measured on board ship by using Boyce's (1976) standard techniques (Site 597 chapter, this volume). As shown in Table 2, the resulting shipboard values range from $2.71 \mathrm{~g} / \mathrm{cm}^{3}$ for Sample 3 (597C-3-1, 119-121 cm) to $2.97 \mathrm{~g} / \mathrm{cm}^{3}$ for Samples 5, 12 , and 20 (597C-4-2, $136-138 \mathrm{~cm}, 597 \mathrm{C}-7-1,50-52 \mathrm{~cm}$, and $597 \mathrm{C}-10-2,135-137 \mathrm{~cm})$. The shipboard-measured bulk-density values are from $2.9 \%$ higher to $2.8 \%$ lower than the values measured in the laboratory; the mean difference is $0.07 \%$.

The grain or mineral density of 13 samples was estimated in the laboratory by subtracting from the measured porosity (described below) the mass and the volume of the pore fluid and recomputing the density. A salt correction is applied to the evaporated water weight (see porosity calculation). The grain densities of the 13 samples range from 2.993 to $3.117 \mathrm{~g} / \mathrm{cm}^{3}$. The mean grain density is $3.050 \pm 0.043 \mathrm{~g} / \mathrm{cm}^{3}$, which is slightly higher than the mean grain density of 8 samples measured on board ship (which was $3.025 \pm 0.023 \mathrm{~g} / \mathrm{cm}^{3}$ ). The range in grain density is considerably smaller than that for bulk density, a relationship that indicates that much of the variation in bulk density arises from variation in porosity rather than from differences in mineralogy.

\section{Porosity Measurements}

Sample wet-water content (percent water by weight) was measured by weighing the samples when seawater saturated and after drying. The initial weighing was performed after the surfaces of each sample were wiped dry. Then the samples were kept under an approximate 20 -in. vacuum at $80^{\circ} \mathrm{C}$ for about $76.5 \mathrm{hr}$. They were weighed at intermediate times in order to determine the rate of water loss.

Figure 1 shows results of 14 weighings during $76 \mathrm{hr}$., $26 \mathrm{~min}$. of drying for three samples with porosities ranging from about $3 \%$ to $9 \%$. Most of the drying occurred in the first $30 \mathrm{hr}$. The asymptotic approach to the dry weight occurs quite rapidly. Weight loss over the first $20 \mathrm{hr}$. or so is primarily diffusive. The continued weight loss at long times may be due to partial dewatering of the clay minerals that occur as alteration products in the samples. However, the amount of water so lost is probably negligible and has a small effect, if any, on the calculations. At most, this additional weight loss may result in a slight overestimate of porosity.

A correction is used to account for the presence of dissolved salts left behind after the vacuum drying of the samples. The correction used assumes an original salinity of $35 \%$ (Boyce, 1976).

The porosities of the 13 samples range from $2.4 \%$ to $9.3 \%$; the mean and standard deviation are $5.2 \pm 2.2 \%$ (Table 1). The mean salt-corrected wet-water content (percent weight) is $1.8 \pm 0.78 \%$.

\section{DISCUSSION}

Both the compressional-wave and shear-wave velocities increase with depth (Fig. 2). The laboratory-measured compressional velocities display a range of about $1 \mathrm{~km} / \mathrm{s}$, and the shear velocities display a range of about $1.5 \mathrm{~km} / \mathrm{s}$ for samples obtained from a range of depths of only $91 \mathrm{~m}$. In Unit I (upper $48 \mathrm{~m}$ of basement), the compressional velocities vary widely (from 5.7 to 6.8 $\mathrm{km} / \mathrm{s}$ ). In Unit II, which is described as being the most evolved unit drilled (Pearce et al., this volume), the compressional velocities are relatively low $(5.8$ to $6.2 \mathrm{~km} / \mathrm{s})$. In Unit III, which is described as being the most primitive in composition (Pearce et al., this volume), the compressional velocities are relatively high $(6.3$ to $6.8 \mathrm{~km} / \mathrm{s})$. Moreover, the lowest measured velocities do not occur solely at the top of the 91-m section, and the highest measured velocities do not occur solely at the bottom. The variations in compressional velocity do not seem to be directly related to the degree of alteration in the samples or to the abundance of vesicles. Analysis of thin sections from the measured samples reveals a close relationship between average grain size and compressional velocity.

Samples 1, 2, 3, 4, and 11 (597B-2-1, 12-14 cm, 597B-2-2, 11-13 cm, 597C-3-1, 119-121 cm, 597C-3-3, $29-31 \mathrm{~cm}$, and 597C-6-4, 122-124 cm) have textures that can be described as subspherulitic to intersertal. The larg- 

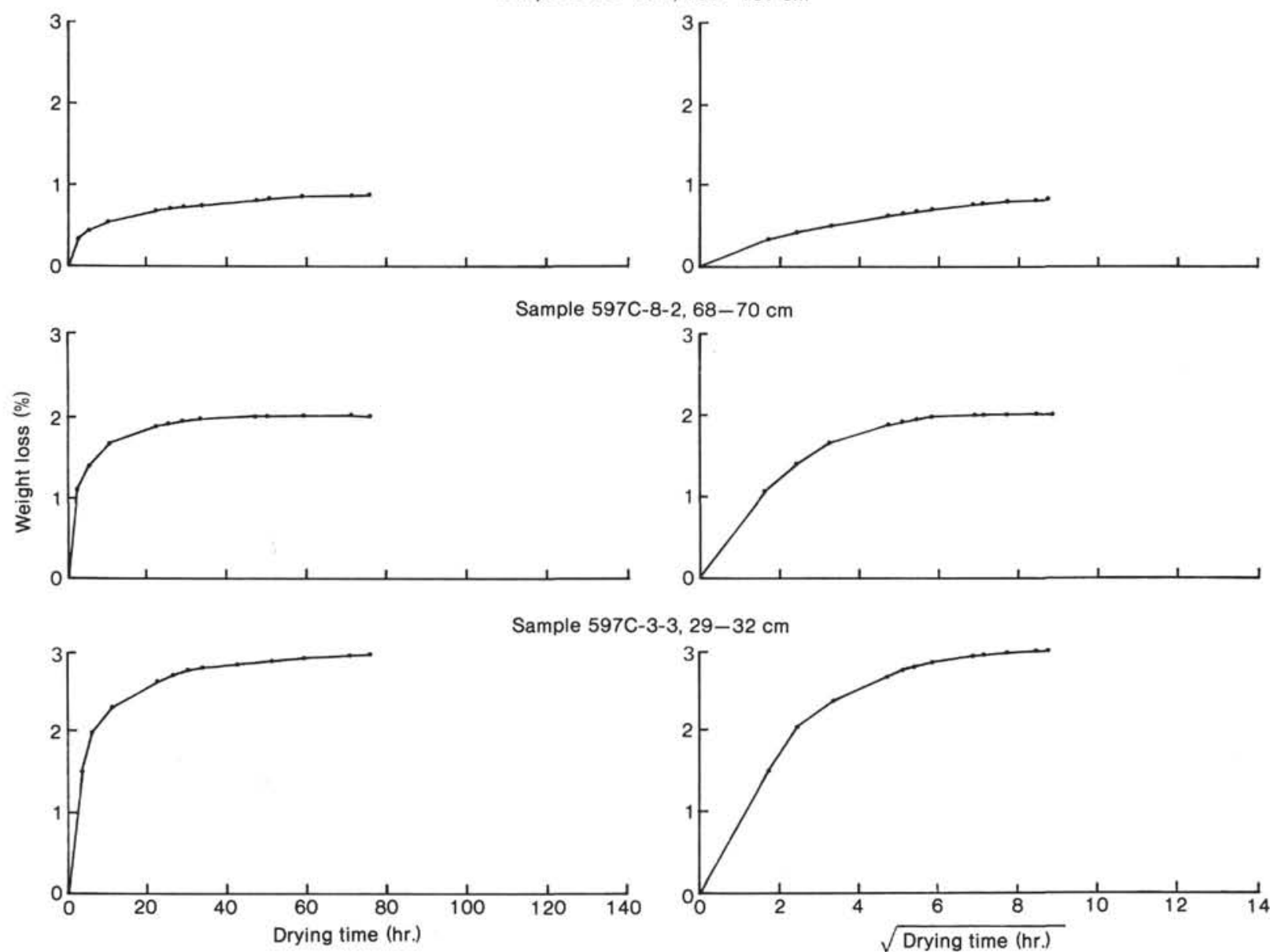

Figure 1. Weight loss as a function of time and the square root of time for three samples from Hole 597C. Most of the drying occurs in the first $30 \mathrm{hr}$. Asymptotic approach to dry weight is rapid.

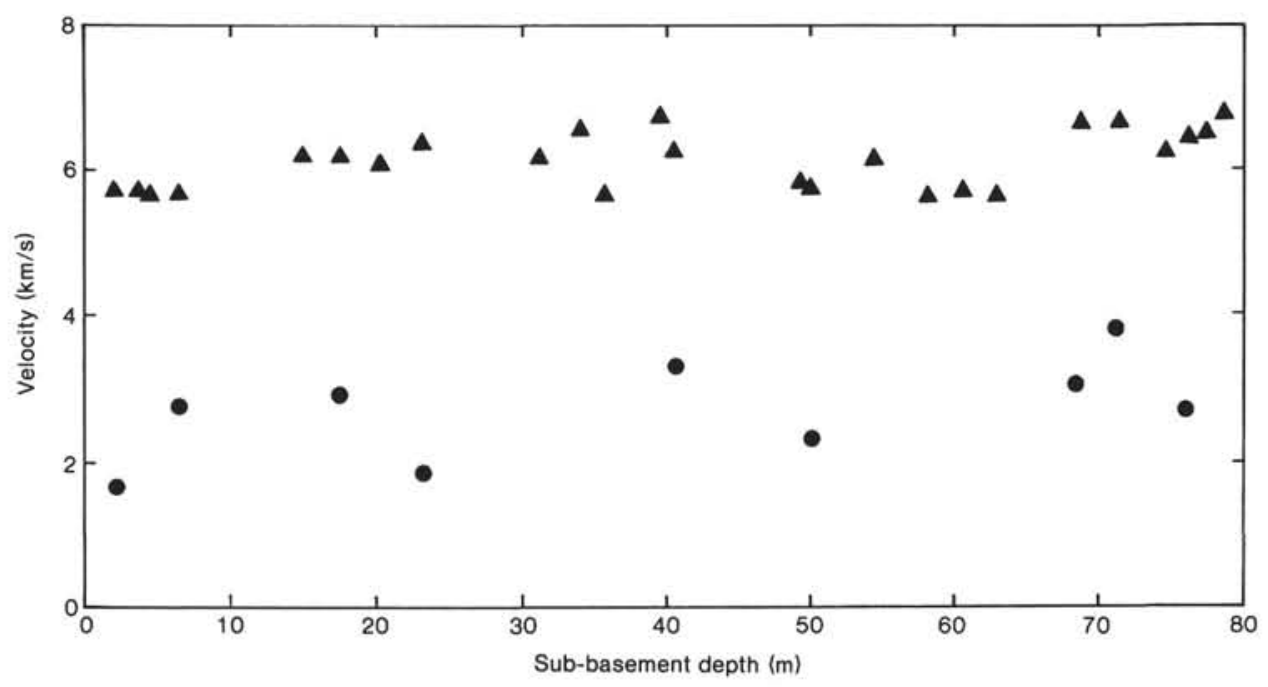

Figure 2. Compressional-wave (triangles) and shear-wave (circles) velocities of samples from Holes 597B and 597C plotted versus sub-basement depth. 
est grains (plagioclase) range in size from 0.5 to $1 \mathrm{~mm}$, but most of them are about $0.5 \mathrm{~mm}$. Samples 14 and 15 (597C-8-1, 134-136 cm and 597C-8-2, 68-70 cm) have subvariolitic to microcrystalline textures, with large grains ranging from 0.5 to $1 \mathrm{~mm}$ in size. Samples 17,18 , and 19 (597C-9-1, 99-101 cm, 597C-9-3, 49-51 cm, and $597 \mathrm{C}-9-4,113-115 \mathrm{~cm}$ ) have ophitic to poikilophitic textures with plagioclase laths $(0.5$ to $2 \mathrm{~mm})$ enclosed in augite. Except for the large plagioclase laths, the average grain size ranges from 0.1 to $0.5 \mathrm{~mm}$. All of these samples have compressional velocities less than $6.0 \mathrm{~km} / \mathrm{s}$ and an average grain size of about $0.5 \mathrm{~mm}$. The samples were recovered from the upper $36 \mathrm{~m}$ of hole.

Samples 5, 6, 7, 9, 13, and 16 (597C-4-2, 136-138 cm, 597C-4-4, 91-93 cm, 597C-4-6, 45-47 cm, 597C-6-1, $114-116 \mathrm{~cm}, 597 \mathrm{C}-7-2,22-24 \mathrm{~cm}$, and 597C-8-5, 35-37 $\mathrm{cm}$ ) have generally intergranular textures, commonly containing glomerophyric or subspherulitic clusters of plagioclase crystals. The size of larger grains in these samples ranges from 1 to $3 \mathrm{~mm}$, and the average grain size of the matrix is about $0.5 \mathrm{~mm}$. These samples have compressional velocities between $6.0 \mathrm{~km} / \mathrm{s}$ and $6.3 \mathrm{~km} / \mathrm{s}$. They were recovered over a $40-\mathrm{m}$ depth interval, from about 15 to $54 \mathrm{~m}$ into basement.

Samples 8, 10, 12, 20, 21, 22, 23, 24, and 15 (597C-5-2, $57-59 \mathrm{~cm}, 597 \mathrm{C}-6-3,122-124 \mathrm{~cm}, 597 \mathrm{C}-7-1,50-52 \mathrm{~cm}$, $597 \mathrm{C}-10-2,135-137 \mathrm{~cm}, 597 \mathrm{C}-10-4,108-110 \mathrm{~cm}, 597 \mathrm{C}-$ 10-7, 71-73 cm, 597C-11-1, 104-106 cm, 597C-11-2, $48-50 \mathrm{~cm}$, and $597 \mathrm{C}-11-3,35-37 \mathrm{~cm}$ ) all have ophitic to poikilophitic textures, with plagioclase laths ranging in size from 0.5 to $4 \mathrm{~mm}$. The average grain size is about 1 to $2 \mathrm{~mm}$, and these samples have compressional velocities greater than $6.3 \mathrm{~km} / \mathrm{s}$. The samples were recovered over a $55-\mathrm{m}$ depth interval, from about 23 to $78 \mathrm{~m}$ into basement.

The samples with a smaller average grain size have lower compressional velocities, and those with a larger average grain size have higher compressional velocities (see Table 3). This relationship is not a surprising, since, barring other factors, a sample with smaller average grain size has a greater intergranular crack density, as the result of the higher surface-to-volume ratio of small grains. The increased crack density will result in a lower effective velocity.

There is considerable variation in the shear velocities of the nine samples for which accurate shear velocities

Table 3. Mean values of compressional and shear velocity and bulk density versus average grain size.

\begin{tabular}{ccccc}
\hline $\begin{array}{c}\text { Average } \\
\text { grain size } \\
(\mathrm{mm})\end{array}$ & $\begin{array}{c}\text { Sample } \\
\text { numbers }\end{array}$ & $\begin{array}{c}\text { Mean } \\
\text { compressional } \\
\text { velocity } \\
(\mathrm{km} / \mathrm{s})\end{array}$ & $\begin{array}{c}\text { Mean shear } \\
\text { velocity } \\
(\mathrm{km} / \mathrm{s})\end{array}$ & $\begin{array}{c}\text { Mean bulk } \\
\text { density } \\
(\mathrm{g} / \mathrm{cm} 3)\end{array}$ \\
\hline $0.1-0.5$ & $\begin{array}{c}1,2,3,4,11,14, \\
15,17,18,19\end{array}$ & $5.76 \pm 0.05$ & $2.41 \pm 0.53$ & $2.837 \pm 0.081$ \\
0.5 & $5,6,7,9,13,16$ & $6.21 \pm 0.06$ & $3.24 \pm 0.24$ & $2.957 \pm 0.047$ \\
$1-2$ & $8,9,10,12,20,21$, & $6.57 \pm 0.19$ & $3.23 \pm 0.46$ & $2.959 \pm 0.053$ \\
& $22,23,24,25$ & & & \\
\hline
\end{tabular}

Note: Mean compressional velocity and mean bulk density were computed from all samples listed. Mean shear velocity was computed from only three samples from each grain size category. were measured. These variations in shear velocity are not directly related to the degree of alteration, vesicle size and abundance, or overall porosity of the samples. The relationship that exists between low compressional velocity and small average grain size is not strong in the shear velocity data, although the samples with the smallest average grain size do have a lower mean shear velocity. Part of this variation may be due to the inherently lower accuracy in determination of shear arrival times. In addition, shear velocities are affected by undetected variations in the density and aspect ratio of cracks not associated with grain boundaries, particularly at these low effective pressures. A more detailed study of these effects would be possible if accurate shear velocity measurements could be made on a larger number of samples at in situ pressures.

Bulk density is plotted against porosity for the 13 samples for which porosity was calculated in Figure 3. Most of the values lie between or near the lines that represent calculated values of constant grain density of 3.0 to 3.1 $\mathrm{g} / \mathrm{cm}^{3}$. This result is in close agreement with the calculated mean grain density of $3.050 \mathrm{~g} / \mathrm{cm}^{3}$. There is a strong linear correlation between the data, indicating that variations in bulk density are controlled by porosity. The relatively uniform values of grain density support this conclusion.

In Figure 4, the compressional and shear velocities are plotted against porosity. Both the compressional and shear velocities decrease with increasing porosity. These relationships indicate that the variations in compressional and shear velocity and bulk density are controlled largely by the porosity of the samples and that variations in the samples' intrinsic properties are comparatively small. This conclusion is supported by the relative chemical and minerological homogeneity of the recovered core (Pearce et al., this volume). Linear extrapolation of these values to zero porosity yields an estimate of the intrinsic physical properties of the basalts from Hole 597C. The resulting values are $3.09 \pm 0.02 \mathrm{~g} / \mathrm{cm}^{3}$ for density, $6.79 \pm$ $0.1 \mathrm{~km} / \mathrm{s}$ for compressional velocity, and $3.4 \pm 0.5 \mathrm{~km} /$

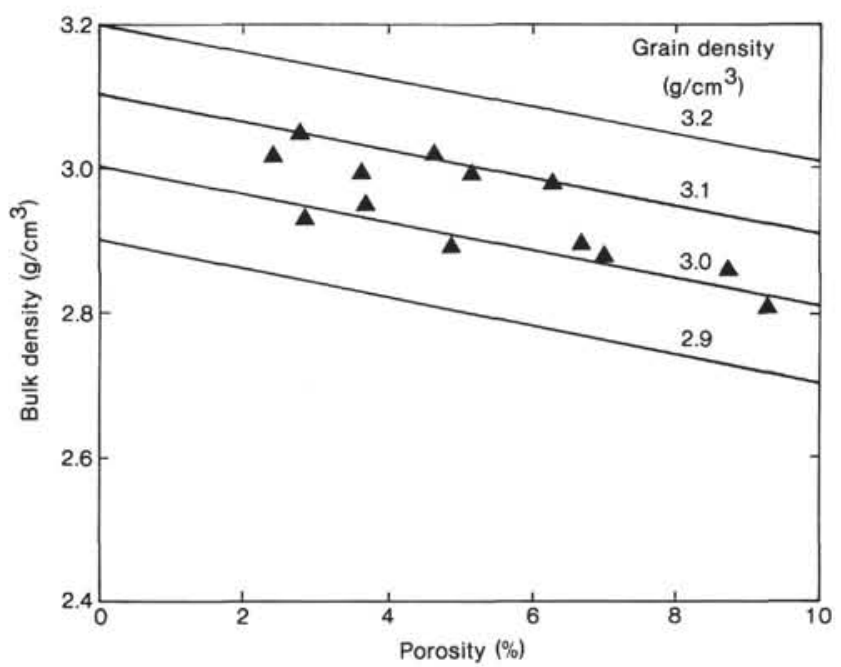

Figure 3. Bulk density versus porosity for selected samples from Holes $597 \mathrm{~B}$ and $597 \mathrm{C}$. 


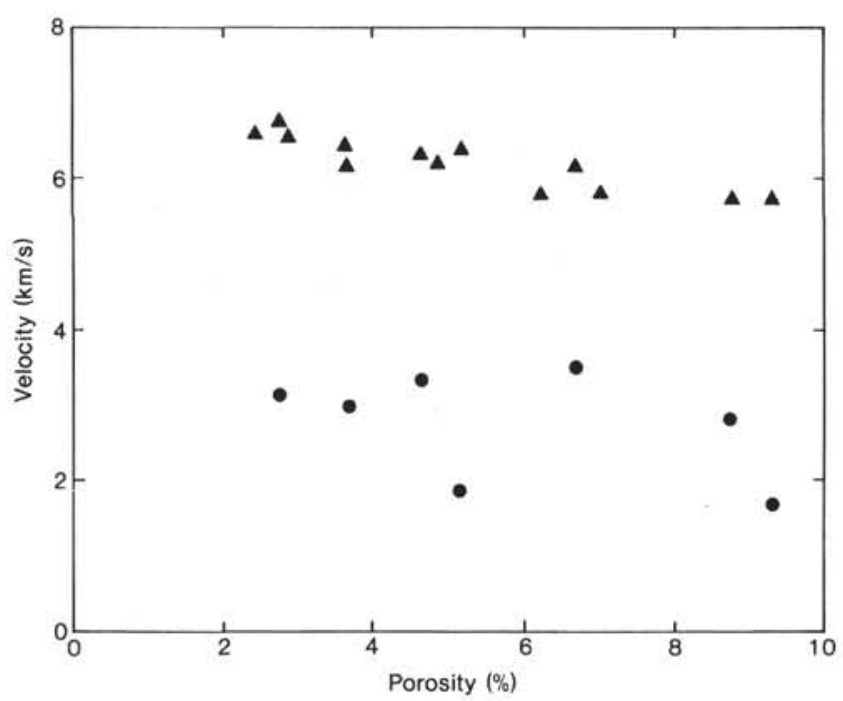

Figure 4. Compressional (solid triangles) and shear (solid circles) velocity versus porosity for samples from Holes 597B and 597C. Both compressional and shear velocities decrease as porosity increases.

$s$ for shear velocity. The density value is quite close to the calculated mean grain density of $3.050 \mathrm{~g} / \mathrm{cm}^{3}$.

Compressional and shear velocities are plotted against density in Figure 5. Velocities measured at 1 kilobar in basalt samples obtained from DSDP Hole 504B during Legs 69 and 70 are shown for comparison (Wilkens et al., 1983). The curves are nonlinear best fits for DSDP basalts from Christensen and Salisbury (1975). Most of their samples were generated at slow-spreading ridges. Both the densities and compressional velocities are relatively high for the Hole 504B, 597B, and 597C samples, which were generated at moderate- to fast-spreading

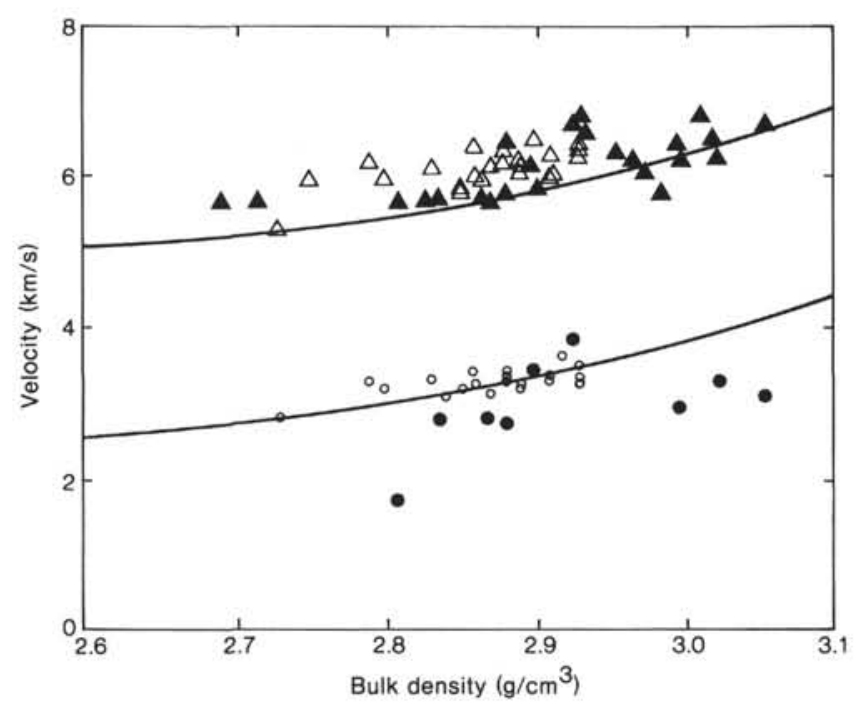

Figure 5. Compressional (solid triangles) and shear (solid circles) velocity versus bulk density of samples from Holes 597B and 597C. Compressional (open triangles) and shear (open circles) velocities of basalt samples from Leg 69 and 70 are shown for comparison (Wilkens et al., 1983). Curves are nonlinear best fits for DSDP basalts from Christensen and Salisbury (1975). After Wilkens et al., 1983. ridges. The high densities and compressional velocities can be explained by the relatively small amount of alteration products in the rocks. The samples from Holes 597B and 597C span a wider range of densities than the Hole 504B samples. In these samples the correlation between velocity and density is less pronounced than in the Hole 504B samples or in the best-fit curve from Christensen and Salisbury (1975). The shear velocities of the samples from Site 597 are low by comparison with samples from other sites with similar densities. Since shearwave velocity is more strongly influenced by crack properties, the low shear velocities of the samples from Site 597 may be a result of the lower effective pressures present during the measurements.

\section{SUMMARY}

Variations in the bulk density of these samples are primarily controlled by porosity. Variations in the compressional and shear velocity are also largely controlled by porosity. These relationships are not surprising, given the compositional homogeneity of the recovered core.

Variations in the compressional velocity appear to be due primarily to the variation in the average grain size of the samples. This relationship has tentatively been explained by the greater density of the grain boundary cracks for samples with a smaller average grain size. No systematic relationship between shear velocity and average grain size is apparent. A larger number of samples for which accurate shear velocities have been measured under in situ conditions would permit a more detailed study of the effects of grain size, crack aspect ratio, and crack density on shear velocity.

On the basis of these results we would expect both compressional and shear velocities to increase with increasing depth in the crust, primarily because of the effects of confining pressure on crack density.

\section{ACKNOWLEDGMENTS}

We would like to thank the officers, crews, and scientific parties of the Glomar Challenger Leg 92 and the French naval vessel Papanoo, without whose cooperation these studies could not have been undertaken. Amos Nur of Stanford University kindly offered the use of his laboratory for the velocity measurements. Daniel Fornari provided valuable assistance in the analysis. This paper was improved by the comments of two anonymous reviewers. This work was supported by $\mathrm{Na}-$ tional Science Foundation grant OCE 81-10919 and Office of Naval Research contracts TO-0098 and TO-0132, scope HH.

\section{REFERENCES}

Birch, F., 1960. The velocity of compressional waves in rocks to $10 \mathrm{ki}-$ lobars, 1. J. Geophys. Res., 65:1083-1102.

1961. The velocity of compressional waves in rocks to 10 kilobars, 2. J. Geophys. Res., 66:2199-2224.

Boyce, R. E., 1976. Definitions and laboratory techniques of compressional sound velocity parameters and wet-water content, wetbulk density, and porosity parameters by gravimetric and gamma ray attenuation techniques. In Schlanger, S. O., Jackson, E. D., et al., Init. Repts. DSDP, 33: Washington (U.S. Govt. Printing Office), 931-958.

Christensen, N. I., and Salisbury, M. H., 1975. Structure and constitution of the lower oceanic crust. Rev. Geophys. Space Phys., 13: 57-86.

Craig, H., Broecker, W. L., and Spencer, D., 1981. GEOSECS Pacific Expedition (Vol. 4): Washington (U.S. Govt. Printing Office).

Hyndman, R. D., 1977. Seismic velocity measurements of basement rocks from DSDP Leg 37. In Aumento, F., Melson, W. G., et al., 
Init. Repts. DSDP, 37: Washington (U.S. Govt. Printing Office), 373-387.

Tosaya, C. A., 1982. Acoustical properties of clay-bearing rocks [Ph.D. dissert.]. Stanford University, Palo Alto.

Wilkens, R. H., Christensen, N. I., and Slater, L., 1983. High-pressure seismic studies of Leg 69 and 70 basalts. In Cann, J. R., Lang- seth, M. G., Honnorez, J., Von Herzen, R. P., White, S. M., et al., Init. Repts. DSDP, 69: Washington (U.S. Govt. Printing Office), 683-686.

Date of Initial Receipt: 16 July 1985 Date of Acceptance: 31 December 1985 